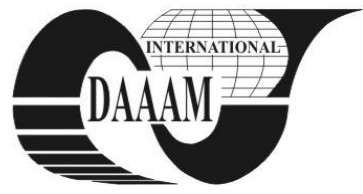

\title{
METHOD OF PROJECTING MODULAR STRUCTURES FOR MANUFACTURING TECHNOLOGY
}

\author{
VOJTKO, I[mrich] \& MIKITA, J[ozef]
}

\begin{abstract}
Aspects of the design of new motion structures, modular machines assembled from modules with unrestricted movement is necessary to grasp methodically. Uniform methodology by analyzing the compilation of kinematic structures built from those modular members. At the end of the article summarizes the steps developed proposal structures modular type machine.
\end{abstract}

Key words: modular machine, modular structure, design methodology, innovation, manufacturing technology

\section{INTRODUCTION}

Manufacturing Technology is constantly evolving branch with lots of innovation. Between the major innovations include the application of the modular principle in this area. Machines based on this principle is characterized by: modularity, scalability, flexibility, high degree of automation, highly sophisticated control, such as. in Fig.1. Management and sensoric subsystem those modular machine control systems is solved with a given specialization, offered by individual producers. Often used with computer control software developed for specific application and that assembly is able to adapt to specific modular construction machine composed of individual modules.

Currently, systems using modular units based on motion rotation, which is often used for simple applications with low demands on accuracy, offering greater or lesser number of modules for the compiling these modular devices.

\section{DESIGN METHODOLOGY}

We know several types of design methodologies and principles of design professionals, AVS, which is managed by algorithm in general and classic design steps. Suggested the need for refinements, respectively innovative approaches to the design of AVS requires the implementation of a modular approach.

Design Methodology is called a summary of the working methods and special techniques developed best practices and methodical management of work. The advantage of work conducted through an appropriate methodology is:

- Allows the purposeful discovery of new technical solutions.

- Creates conditions that were considered all the appropriate solutions for the implementation of certain functions.

- Rationalize the entire process of solving the problem on the basis of established procedure and thus saves time.

- Makes it easier selection of optimal solutions.

- Methodological procedure creates a presumption algorithm and to use computer technology.

Until now compiled by employing the methodology of constructing the systems approach to design (construction of the system), where phenomena are understood and considered in their complex internal and external connections built in:
- Sequences conscious, and to describe and formalizing activities.

- Structured and hierarchical (level structure) understanding the design of the building.

- Approach to solving technical object through of its dedicated function resulting from the application requirements.

- Systematic approach to the construction of the technical object object based on decomposition of elements and sets up the investigation of their properties, relationships and bonds.

- Developing algorithms for each step solutions for creating subalgoritm's detailed steps of the solution

- Analysis and allocation of technical object on the principle-based practices based on dependency tracking input / output, cause / effect, partial solution / complex solution.

- Equilibrium solutions built on efficiency solutions.

- Prediction models of development and innovation, functionality and technical characteristics of object, constructed in anticipation of future reconstruction and object of technical innovation.

- Necessity to take account of relationships, dependencies and functionality of the man - a technical facility in operation.

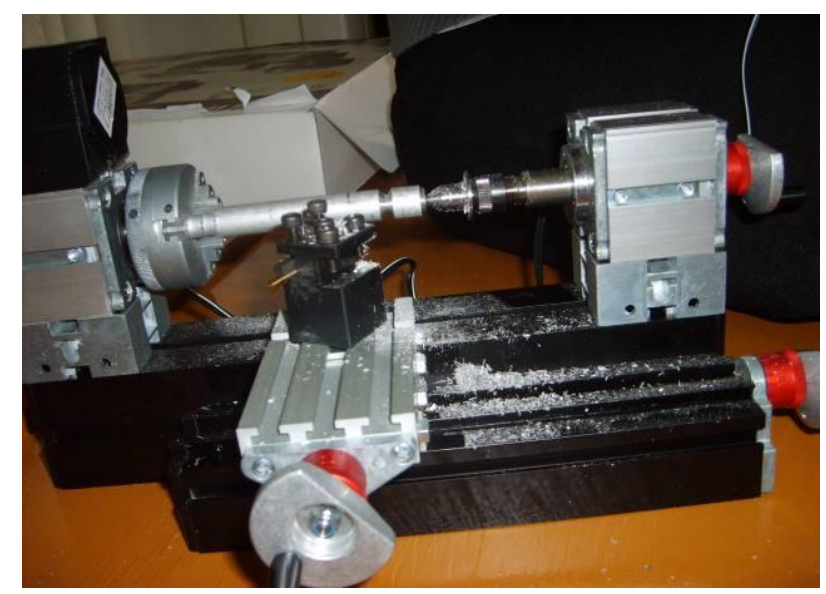

Fig. 1. Functional model of simple modular man. machine

\section{THE MAIN PRINCIPLES FOR DESIGN OF MODULAR STRUCTURES}

Technical activities associated with the creative design process is a sequence of solutions to problem situations related to creating technical design of the building and prognosis of future properties of this object. Technical activities associated with the proposal of the technical object can be divided into:

- Creative - there is a new quality in comparison with the current state 
- Executive - necessary for the implementation of the outcome of creative activity.

- Organisational - creating conditions for creative work of the designer

- Informational - gathering, sorting, processing and use of information.

To solve problem situations can use one of these procedures:

- Intuition - a solution based on the subconscious level of brain activity.

- Modeling - to prognosis the performance model created using object technology

- Experience - intensive subconscious processes in the mind of the designer on the basis of of its practice, study, and knowledge is retrieved. Experience is closely linked with intuition.

- Copying - designing under the existing (competitive) model without a detailed analysis.

- Routinism - subconscious repetition of procedures already used (native, foreign) with varying proportions of hange.

- Taking risks - routinism with a high proportion of significant changes.

- Experiment - the progressive design verification at different stages of the design object.

Using the methodology designers can build a modular manufacturing machine, such as milling machine of Fig. 2. It is a tri-axial manually controlled vertical milling machine designed for hobby purposes. In addition to such a machine is possible to build a CNC machine from the same number of components, but moving units exchanged modules for $\mathrm{CNC}$ controlled manner with servomotors. After this adjustment we obtain a full 3D CNC milling machine with many possible variations for machining of smaller components with lower accuracy. Is used to control program MACH3, or any other similar software able to manage 3, 4-axis machines in real time.

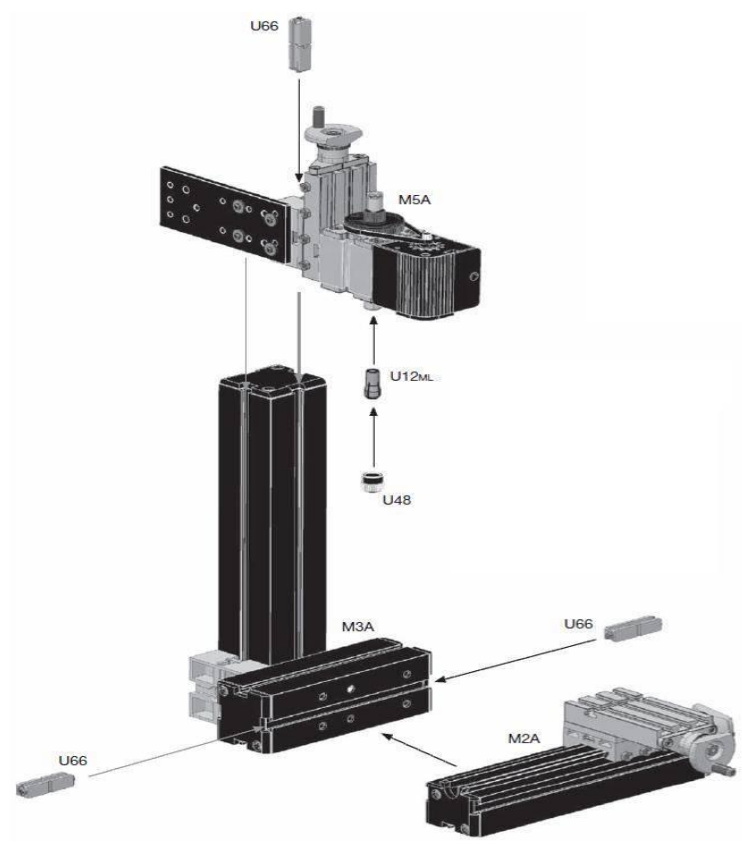

Fig. 2. System structure modular manufacturing machine.

\section{CONCLUSION}

In terms of the sequence in the construction of modular machine developed methodology is needed, particularly for novice designers and users of such systems. According to the methodology developed is appropriate to proceed with construction of the production machine, which has previously met the requirements of the contractor role.

\section{ACKNOWLEDGEMENTS}

This contribution has been supported by research grant KEGA 3/7167/09 (Proposal of interactive educational manual for the area of computer systems support the technological preparation of production).

\section{REFERENCES}

Baron, P.; Kočiško, M. (2006). Technologická príprava výroby a procesy posudzovania a manažérstva rizika, $M M$ Prùmyslové spektrum, 5, (2006), 108-109, ISSN 1212-2572

Berežný, Š. et al. (2007). Another mathematical optimization models based on assignment problem, Acta Montanistica Slovaca. 12, 4, 356-360, ISSN 1335-1788

Brychta, J. et al. (2007). Technologie II - 1. díl. Ediční středisko VŠB - TU Ostrava. ISBN 978-80-248-1641-8. Ostrava

Demeč, P.; Varchola, M.; Svetlík, J. (2010). Useing of mechatronics systems in designing of manufacturing machines. Metalurgija, 49, 2, (2010), 604-608, ISSN 05435846

Horodníková, J.; Khouri, S. (2007). Organizácia a riadenie výroby, 1. vyd., FBERG TU Košice, ISBN 978-80-8073915-7, Košice

Hricová, B. et al. (2010) Aplication of ecodesign and life cycle assessment in evaluation of machine products. Journal of Production Engineering. 13, 1, 69-72. ISSN 1821-4932.

Kočiško, M.; Baron, P. (2008). Návrh ultrazvukovej bezpečnostnej brány pre strojné zariadenia, Výrobné inžinierstvo, 7, 2, (2008), 72-74, ISSN 1335-7972

Krehel', R.; Dobránsky, J. (2010). Aplikácia dátového analyzujúceho procesu v systéme identifikácie topografie povrchu obrobku, Strojírenská technologie, 14, (2010), 116-119, ISSN 1211-4162

Krehel', R.; Dobránsky, J. (2009). Návrh systému pracujúceho v diagnostike procesu výroby, Technika, 7, 9, (2009), 46-47, ISSN 1337-0022

Monka, P.; Monková, K. (2009). Process plans design in relation to increasing of production efficiently, Scientific Bulletin, 23, C, (2009), 239-244, ISSN 1224-3264

Panda, A. et al. (2009). Vývoj, výroba a overenie nových výrobkov pre automobilový priemysel - 1. čast', FVT, ISBN 978-80-553-0149-5, Prešov

Pekarčíková, M.; Bobková, D.; Turisová, R. (2009). Modelovanie demontážnych procesov z hladiska optimálnej využitel'nosti dožitého produktu, Manažment v teórii a praxi, 5, č. 1-2 (2009), 75-84, ISSN 1336-7137

Svetlík J.; Naščáková J. (2007). Assembled system of modular robots, Trendy v systémoch riadenia podnikov, Košice, TU SjF, 1-5, ISBN 9788080738853

Šebo, J.; Fedorčáková, M.; Jurčišin, R. (2009). Basic indicators of measuring productivity and their application on machinery production orders. Intercathedra, 25, 132-136, ISSN 1640-3622

Šebo, D.; Trebuňa, P. (2007). Logistika strojárskeho výrobného procesu, Acta Mechanica Slovaca, 11, 3, (2007), 107-114, ISSN 1335-2393

Sinay, J.; Markulík, Š. (2010). Nové trendy v oblasti manažmentu rizík. Ergonómia: progresívne metódy $v$ ergonómii, SES, 7-13. ISBN 978-80-970588-6-9

Turisová, R.; Pekarčíková, M. (2009). Effect of usefulness of machines and equipments on usability of cost function on TPM, Acta economica cassoviensia, 2, č. 1, 104-111, ISSN $1337-6020$ 